\title{
ACRL list of materials available
}

\section{A complete checklist of ACRL publications in print.}

$S$

ingle copies of ACRL standards and guidelines are free upon request (additional copies may be purchased for $\$ 1.00$ each). Other publications are priced as listed. To ensure that your order is properly processed, include ISBN, author, title, list price, and applicable discount for each item ordered.

Both institutions and individuals may order on account, plus postage and handling; however, prepayment should accompany individuals' orders of $\$ 15.00$ or less. No postage or handling charges are added to prepaid orders (check, money order, credit card). All prices are payable in U.S. funds. The first price stated is list price.

ISBN prefix: $0-8389-$.

\section{Discounts}

ALA personal and organizational members are eligible to receive a ten percent $(10 \%)$ discount on ACRL materials (except subscription items). To receive the discount, give your membership number, and deduct the discount when preparing your orders.

ACRL personal and organizational members receive an additional $10-30 \%$ discount on ACRL materials. Look for the ACRL member prices on this list.

Quantity discounts are available when five or more copies of the same title are ordered to be shipped to the same address. Inquire for prices on specific titles.

\section{Handling charges}

Invoice amounts of $\$ 20.00$ or less, $\$ 1$. Invoice amounts of $\$ 20.01-\$ 50.00, \$ 2$.

Invoice amounts of $\$ 50.01-\$ 100.00, \$ 3$.

Invoice amounts of $\$ 100.01-\$ 200.00, \$ 4$.

Invoice amounts greater than $\$ 200.00, \$ 5$.

Send completed orders to: ALA Publishing Ser- vices, Order Department, 50 E. Huron Street, Chicago, IL 60611-2795.

\section{ACRL approval plans}

The convenient ACRL approval order plan provides automatic priority shipping of ACRL's new books at a $20 \%$ discount to ACRL members (10\% to non-members). There are two approval plan categories to choose from. Plan "P" guarantees that you will automatically be sent all new ACRL publications. Plan "PC" is exclusively for titles in the CLIP Notes series. You may change or cancel your approval order at any time and you do have return privileges. For details, contact Mary Ellen Davis, ACRL Publications Officer.

\section{Bibliographic instruction}

- Back to the Books: Bibliographic Instruction and the Theory of Information Sources (1983). Papers presented at the Bibliographic Instruction Section program at the 1982 ALA Annual Conference. Edited by Ross Atkinson. 76p. 6587-3. \$15; ACRL members $\$ 12$.

-The Bibliographic Instruction Clearinghouse: A Practical Guide (1984). A guide to establishing a clearinghouse. 7lp. 6775-2. \$12; ACRL members $\$ 9$.

- Bibliographic Instruction Handbook (1979). Prepared by the ACRL Bibliographic Instruction Task Force (1971-77) and the Policy and Planning Committee of the ACRL Bibliographic Instruction Section (1977-79). “...provides the librarian with information which, when joined to will and talent, should result in a successful program"-Journal of Academic Librarianship. 68p. 6729-9. \$10; ACRL members $\$ 7$.

- Evaluating Bibliographic Instruction: A Handbook (1983). Prepared by the ACRL Bibliographic Instruction Section's Subcommittee on 
Evaluation. “...one of the most practical and useful publications in the area of user instruction"Library \& Information Science Research. 122p. 6608-X. \$17; ACRL members \$13.

- Library Instruction Clearinghouses 1986: A Directory. By Mary Van Orsdol. 7109-1. \$5; ACRL members $\$ 4$.

- Organizing and Managing a Library Instruction Program (1979). Prepared by the ACRL Bibliographic Instruction Section's Continuing Education Committee. 30p. 6731-0. \$4; ACRL members $\$ 3$.

- Petals Around a Rose: Abstract Reasoning and Bibliographic Instruction (1980). By Cerise Oberman-Soroka. 23p. 6732-9. \$5; ACRL members $\$ 4$.

\section{Collection development}

- Books for College Libraries, 3d ed. Six volumes. Forthcoming in 1988. Inquire for publication date and price.

- Building a Children's Literature Collection (1983). 3rd ed. Choice Bibliographical Essay Series, no. 7. \$9.95. 48p. 0-9144-9206-3. Order from: Choice, 100 Riverview Center, Middletown, CT 06457.

-Building Women's Studies Collections: A Resource Guide (1987). Edited by Joan Ariel. Choice Bibliographical Essay Series, no. 8. \$12. 48p. 09144-9207-1. Order from: Choice, 100 Riverview Center, Middletown, CT 06457.

- Collection Development Policies: CLIP Note \#2-81 (1981). 131p. 6738-8. \$12; ACRL members $\$ 9$.

-Curriculum Materials Center Collection Development Policy (1984). 27p. 6777-9. \$7; ACRL members $\$ 5$.

- Guide for the Development and Management of Test Collections with Special Emphasis on Academic Settings (1985). Prepared by the ACRL Education and Behavioral Sciences Section's Ad Hoc Subcommittee on Test Collections. "Any question a librarian might have on the subject of test collections appears to have been answered in the Guide..."-Library Journal. 69p. 6926-7. \$12; ACRL members $\$ 9$.

-Women's Studies in Western Europe: A Resource Guide (1986). Edited by Stephen Lehmann and Eva Sartori. "The well-edited result gives American librarians and researchers an overview of the field plus specific information about acquisitions of feminist publications from western Europe...A valuable resource for academic or large public libraries."-Choice. 129p. 7037-0. \$18; ACRL members \$15.

\section{Conference proceedings}

- Academic Libraries: Myths and Realities (1984). Proceedings of the Third National ACRL Conference, April 4-7, 1984, Seattle. 420p. 67876. \$28; ACRL members $\$ 20$.
- Energies for Transition (1986). Proceedings of the Fourth National ACRL Conference, April 9-12, 1986, Baltimore. Edited by Danuta A. Nitecki. "... a good cross-section in this one volume of the current issues and new developments related to academic librarianship."-College \& Research Libraries. 248p. 6976-3. \$30; ACRL members \$22.

- Libraries and Accreditation in Institutions of Higher Education (1981). Proceedings of an invitational conference sponsored by ACRL and COPA. Edited by Julie A.C. Virgo. “... useful to academic librarians and library schools for the purpose of understanding better the role of the library in the accreditation process." -Journal of Academic Librarianship. 176p. 6741-8. \$19; ACRL members $\$ 15$.

- New Horizons for Academic Libraries (1978). Sixty-six contributed papers from the First National ACRL Conference in Boston. Twelve microfiche. Free.

-Options for the 80's (1981). Fifty-six contributed papers from the Second National ACRL Conference in Minneapolis. Eleven microfiche. Free.

\section{Database searching}

- Online Bibliographic Database Searching in College Libraries: CLIP Note \#4-83(1983). Compiled by David Carlson and P. Grady Morein. 132p. 6624-1. \$19; ACRL members \$15.

\section{Directories}

- Directory of Curriculum Materials Centers (1985). Compiled by Lois J. Lehman and Eva K. Kiewitt. 2nd ed. “...an invaluable work which will be heavily used by all who are associated with education collections, instructional materials centers, and teacher training institutes."-Library \& Information Science Annual. 194p. 6917-8. \$20; ACRL members $\$ 15$.

-Directory of Western European Specialists in North American Libraries (1984). 20p. 6762-0. \$5; ACRL members $\$ 3$.

- Slavic Ethnic Libraries, Museums and Archives in the United States: A Guide and Directory (1980). Compiled by Lubomyr R. Wynar. 164p. 6742-6. \$9; ACRL members $\$ 6$.

\section{Personnel issues and faculty status}

-Management and Staff Development (1982). Proceedings of a workshop sponsored by the Northern California ACRL Chapter in 1979. 37p. 67353. $\$ 10$; ACRL members $\$ 8$.

- Managing Student Workers in College Libraries: CLIP Note \#7 (1986). Compiled by Michael D. Kathman and Jane McGurn Kathman. 182p. 7097-4. \$17; non-members $\$ 14$.

- Travel Policies of Twenty-One College \& University Libraries (1980). 77p. 6736-1. \$3. 


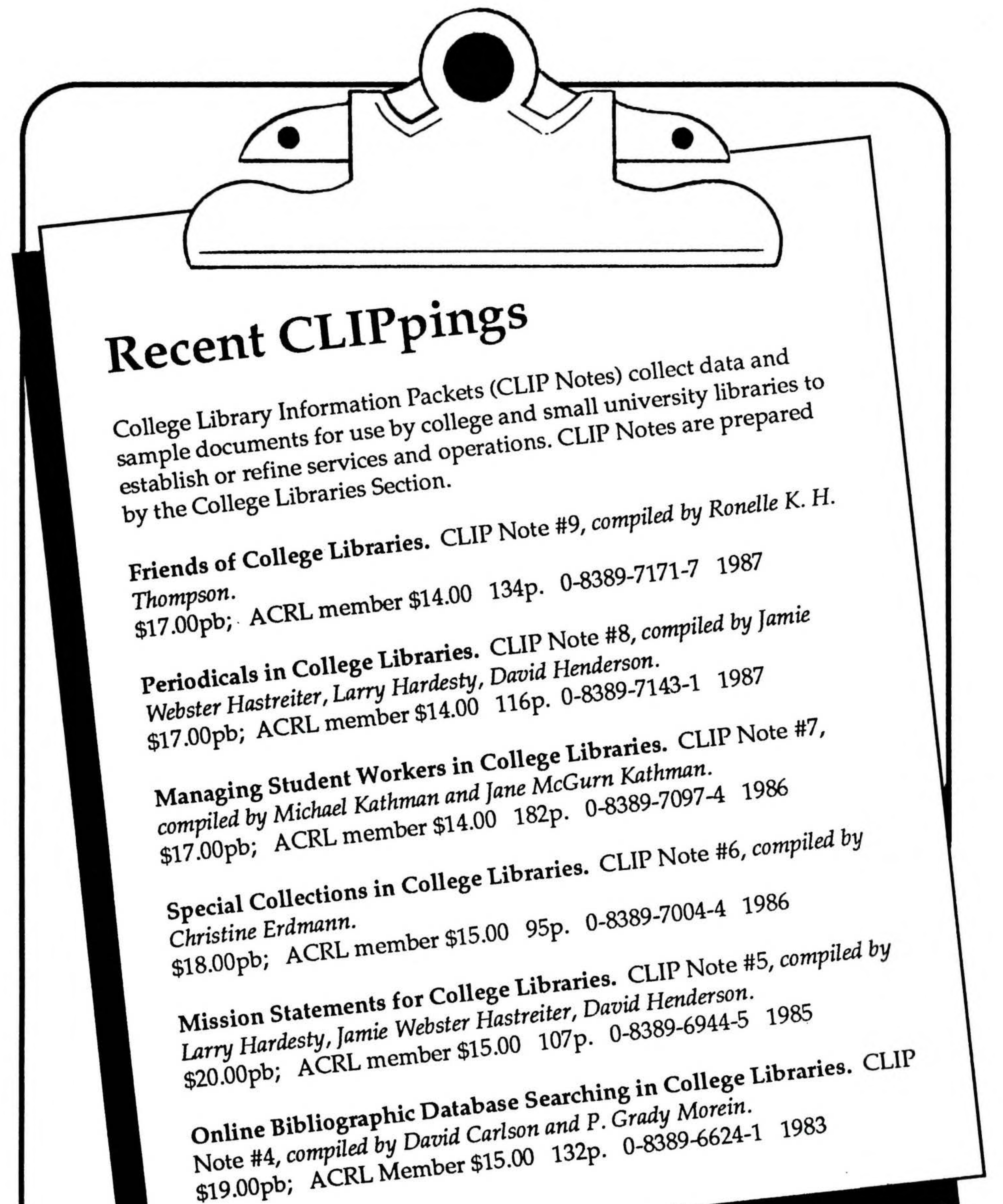

Association of College and Research Libraries

A division of the American Library Association

c/o ALA Publishing Services, Order Department

50 East Huron Street • Chicago, Illinois 60611-2795 


\section{Planning}

- Friends of College Libraries: CLIP Note \#9 (1987). Compiled by Ronelle Thompson. 134p. 7171-7. \$17; ACRL members \$14.

- Mission Statements for College Libraries: CLIP Note \#5 (1985). Compiled by Larry Hardesty, Jamie Hastreiter, and David Henderson. "The survey is a good one, eliciting answers to questions about why and how libraries developed statements of purpose, or why not... a commendable production."-RQ. 107p. 6944-5. \$20; ACRL members $\$ 15$.

\section{Rare books, manuscripts and archives}

- Genre Terms: A Thesaurus for Use in Rare Book and Special Collections Cataloguing (1983). 41p. 6612-8. \$7.50; ACRL members $\$ 5.50$.

- Printing and Publishing Evidence: Thesauri for Use in Rare Book and Special Collections Cataloguing (1986). 28p. 7108-3. \$7.50; ACRL members $\$ 5.50$.

-Special Collections in College Libraries: CLIP Note \#6 (1986). Compiled by Christine Erdmann. Contains actual documents from college libraries on projects, publicity, financial support, archives, preservation, and use policies. 95p. 7004-4. \$18; ACRL members $\$ 15$.

\section{Statistics}

- ACRL University Library Statistics 1985-86 and 1986 "100 Libraries" Statistical Survey (1987). Compiled by Robert Molyneux. Statistics from 149 non-ARL university, college, and junior college libraries. 7144-X. $\$ 30$; ACRL members $\$ 24$.

- ACRL University Library Statistics 1983-84 (1985). Compiled by Sandy Whiteley. Statistics from 86 non-ARL university libraries in the U.S. and Canada. 55p. 6892-9. \$15; ACRL members $\$ 12$.

-ACRL University Library Statistics 1981-1982 (1983). Statistics from 92 non-ARL university libraries. 55p. 6596-2. \$15; ACRL members $\$ 12$.

-ACRL University Library Statistics 1978-1979 (1980). Statistics from 98 non-ARL university libraries. 47p. 6739-6. \$7.50; ACRL members $\$ 5$.

- Library Statistics of Colleges and Universities, 1985: National Summaries, State Summaries, Institutional Tables (1987). Data from the $1985 \mathrm{HE}$ GIS study conducted by the Center for Education Statistics covering 2,870 academic libraries. $240 \mathrm{p}$. 7147-4. \$30; ACRL members $\$ 24$.

- Library Statistics of Colleges and Universities, 1982 Institutional Data (1984). Data from the 1981-82 HEGIS study conducted by the National Center for Education Statistics covering over 3,000 academic libraries. 177p. 6640-3. \$16; ACRL members $\$ 12$.

-1984 “100 Libraries” Statistical Survey (1984).
Task Force on Academic Library Statistics. 92p. 6951-8. \$12; ACRL members $\$ 9$.

-Quantitative Criteria for Academic Research Libraries (1984). By Kendon L. Stubbs. 135p. 6788-4. \$19; ACRL members $\$ 15$.

\section{Periodicals}

- Choice. Book and non-print review journal of the Association of College \& Research Libraries. Eleven issues per year; (July/August combined.) ISSN: 0009-4978. Editor/Publisher: Patricia Sabosik. Available by subscription only, $\$ 110 /$ year. Order from: Circulation Department, Choice, 100 Riverview Center, Middletown, CT 06457.

- Choice Reviews-on-Cards. Reviews from each monthly issue of Choice printed on $3 \times 5$ cards. Available to Choice subscribers only for $\$ 175 /$ year. Order from: Circulation Department, Choice, 100 Riverview Center, Middletown, CT 06457.

- College \& Research Libraries. Official journal of the Association of College and Research Libraries. Six bimonthly issues per year. Editor: Charles R. Martell Jr., California State University Library, Sacramento, CA 95819. Sent to ACRL members as a perquisite of membership. Also available on subscription, $\$ 35 /$ year. ISSN: 00100870. Order from: Subscription Department, American Library Association, 50 East Huron Street, Chicago, IL 60611.

- College \& Research Libraries News. Official news magazine of the Association of College and Research Libraries. Eleven issues per year; (July/August combined). Editor: George M. Eberhart, ACRL/ALA, 50 East Huron Street, Chicago, IL 60611. Sent to ACRL members as a perquisite of membership. Also available on subscription, $\$ 15 /$ year. ISSN: 0099-0086. Order from: Subscription Department, American Library Association, 50 East Huron Street, Chicago, IL 60611.

-Fast Job Listing Service. A job listing which supplements in a speedy, timely fashion the classified advertising in $C \downarrow R L$ News. Published twelve times per year. Six-month subscription. \$15; ACRL members $\$ 10$. Order from: ACRL/ALA, 50 East Huron Street, Chicago, IL 60611.

- Index for Volumes 26 to 40 (1965-1979) of College \& Research Libraries and College \& Research Libraries News (1980). Prepared by Eldon W. Tamblyn. 6482-6. \$12; ACRL members \$10.

- Rare Books and Manuscripts Librarianship. Two issues per year. Available by subscription only. ISSN: 0884-450x. \$20 U.S. and Canada; $\$ 25$ overseas.

\section{CE course syllabi}

-Operating and Marketing Fee-Based Services in Academic Libraries: A Small Business Approach (CE 108a) provides information to enable administrators and librarians from academic libraries to critically analyze fee-based service operations. By Barbara Stump. 1985. 57p. 6965-8. \$15; ACRL 
members $\$ 10$.

-Interviewing Skills: Finding the Right Person for the Job (CE 109) reviews the legal guidelines affecting employment. Considers all aspects of conducting effective evaluative interviews. By Sheila Creth. 1982. 20p. 6875-9. \$15; ACRL members $\$ 10$.

- Teaching Methods for the Bibliographic Instruction Librarian (CE 202) provides an introduction to basic learning theory and alternate instructional methods used in library instruction. By
Marilla Svinicki. 1981. 62p. 6751-5. \$15; ACRL members $\$ 10$.

- How to Teach Science Reference Materials (CE 205), 2d ed., examines the search strategies and reference tools that are particularly useful to undergraduate science majors. By Thomas Kirk. 1984. 63p. 6756-6. \$15; ACRL members $\$ 10$.

\section{ACRL Publications in Librarianship}

-No. 39-Libraries for Teaching, Libraries for

\section{ACRL standards and guidelines}

Single copies of ACRL standards and guidelines are available free upon request. Additional copies may be purchased for $\$ 1.00$ each. Prepayment must accompany orders for additional standards. Send all requests to: ACRL Standards and Guidelines, ACRL/ALA, 50 E. Huron St., Chicago IL 60611.

\section{Access}

Access Policy Guidelines (1975). Reprinted from C $b R L$ News, November 1975. 2p.

\section{Bibliographic instruction}

Guidelines for Bibliographic Instruction in Academic Libraries (1977). Reprinted from CむRL News, April 1977. 1p.

\section{Colleges and universities}

Guidelines for Branch Libraries in Colleges and Universities (1975). Reprinted from $C \mho R L$ News, October 1975. 3p.

Guidelines for Extended Campus Library Services (1982). Reprinted from C\&RL News, March 1982. 2p.

The Mission of an Undergraduate Library (Model Statement). Reprinted from $C \triangleleft R L$ News, November 1979. 5p.

Standards for College Libraries (1986). Reprinted from C $U R L$ News, March 1986. 12p.

Standards for University Libraries (1979). Reprinted from C\&RL News, April 1979. ACRL/ARL. 10p.

\section{Community and junior colleges}

Guidelines for Two-Year College Learning Resources Programs (1982). Reprinted from $C \triangleleft R L$ News, January and February 1982. ACRL/AECT. 10p.

Statement on Quantitative Standards for Two-Year Learning Resources Programs (1979). 4p.

\section{Personnel issues and faculty status}

Guidelines and Procedures for the Screening and Appointment of Academic Librarians (1977). Reprinted from C $\measuredangle R L ~ N e w s$, September $1977.4 \mathrm{p}$.

Joint Statement on Faculty Status of College and University Librarians (1974). ACRL/AAUP/AAC. Reprinted from C $\& R L$ News, February 1974. 1p.

Model Statement of Criteria and Procedures for Appointment, Promotion in Academic Rank, and Tenure for College and University Librarians (1973). Reprinted from $C \triangleleft R L$ News, May 1987. 8p.

Standards for Faculty Status for College and University Librarians (1974). Reprinted from CむRL News, May 1974. 2p. lp.

Statement on Collective Bargaining (1975).

Statement on the Terminal Professional Degree for Academic Librarians (1975). 1p.

\section{Rare books, manuscripts and archives}

Guidelines for the Security of Rare Book, Manuscript, and Other Special Collections (1983). Reprinted from C $b R L$ News, March 1982. $4 \mathrm{p}$.

Guidelines on Manuscripts and Archives (1977). Compilation of policy statements prepared by the ACRL Rare Books and Manuscripts Section's Committee on Manuscripts Collections. Contains: Statement on Appraisal of Gifts; Statement on Legal Title; Statement on the Reproduction of Manuscripts and Archives for Noncommercial Purposes; Statement on the Reproduction of Manuscripts and Archives for Commercial Purposes; and Universal Gift Form and Instructions. 11p.

Joint Statement on Access to Original Research Materials (1979). This supersedes the 1976 ACRL Statement on Access and the 1974 Standards for Access of SAA (American Archivist, January 1974). Reprinted from $C \mho R L$ News, April 1979. 2p. 
Research: Essays for a Century. Richard D. Johnson, ed. (1977). "... a must for all library school students interested in academic librarianship."ARBA 78. 276p. 0247-2 (use order code 3196-0). Limited quantities. $\$ 15$.

- No. 41-Women View Librarianship: Nine Perspectives. Kathryn Renfro Lundy, ed. (1980). "It is satisfying to read their considered responses to questions ranging from ideas about administration and personal career choices to developing library school curricula and advice to beginning professionals."-College \& Research Libraries. 99p. 3251-7. \$8.

-No. 42-The Spirit of Inquiry in Library Science: The Graduate Library School at Chicago, 1921-1951. John V. Richardson Jr. (1982). “...a significant book in library education and an example of painstaking historical research." $-A R B A 84$. 238p. 3273-8. Limited quantities. \$35.
-No. 43-The Landscape of Literatures: Use of Subject Collections in a University Library. Paul Metz. (1983). "Metz provides... an important use study... by attempting to identify the subject literature of interest to faculty and students in various academic disciplines." $-R Q$. 157p. 3286-X. Limited quantities. $\$ 30$.

- No. 44-The Carnegie Corporation and the Development of American College Libraries, 1928-1941. Neil A. Radford. (1984). Provides a useful historical perspective on collection analysis and external funding by studying the impact of Carnegie grants for collection development. 272p. 3295-9. Limited quantities. \$29.95.

- No. 45-English and American Literature: Sources and Strategies for Collection Development. William McPheron, ed. 217p. 0476-9. $\$ 29.95$.

\section{How to publish in ACRL: Non-serial publications}

Are you working on a survey, directory, pamphlet, bibliography, or any other project with publication potential? Then you need to be aware of the publication procedures for non-serial publications developed by the ACRL Publications Committee.

Your publication proposal will go through the following steps on the way to becoming an ACRL or ALA publication.

Step One. Fill out a "Preliminary Publication Information Form," available from ACRL Headquarters, early in the planning stages of your project. This form asks for basic information about the scope and content of the proposed publication and the individual(s) responsible for developing it. Send the completed form to Mary Ellen Davis, ACRL's publications officer, at ACRL Headquarters.

Step Two. The ACRL publications officer reviews the proposal and offers ALA Publishing Services the first chance of accepting the project as an ALA publication. This "right of first refusal" is specified in the operating agreement between ALA and its divisions.

Step Three. ACRL's Publications Subcommittee on Non-Serial Proposals and the ACRL publications officer review the content and viability of the proposal and make a recommendation as to its feasibility. (In some cases, an outside reader with expertise in the subject area will be asked to review the publication for editorial content. This review will next be considered by the Subcommittee and the program officer.) The Subcommittee will review and act upon publication proposals throughout the year, as well as at ALA annual conferences and midwinter meetings.

Step Four. After reviewing the recommendations of the Subcommittee (and any outside reviewers) the ACRL publications officer then accepts, rejects, refers back to ALA Publishing Services, or asks for further development of each proposal from the author or sponsoring body.

Step Five. If your proposal is accepted, submit your completed manuscript to ACRL Headquarters for further review by the Subcommittee and the ACRL publications officer.

For further information, contact Mary Ellen Davis, ACRL Publications Officer, ACRL/ALA, 50 East Huron St., Chicago, IL 60611-2795; (312) 944-6780, x287.

\section{Planning grants for public programs on the Columbian Quincentenary}

The 500th anniversary of Christopher Columbus's first voyage to the New World will be observed internationally in 1992. In honor of this occasion the National Endowment for the
Humanities is holding a special competition for planning grants in Public Humanities Projects. Projects should focus on the scholarly issues raised by the Columbian Quincentenary. Colleges and 